\title{
Bone Angiosarcoma
}

National Cancer Institute

\section{Source}

National Cancer Institute. Bone Angiosarcoma. NCI Thesaurus. Code C6479.

A high-grade malignant vascular neoplasm that arises from the bone. It is characterized by the presence of neoplastic cells with endothelial differentiation. 